\title{
Pattern of knowledge and attitude of women in reproductive age group about
}

\section{Caesarean Section in Basrah city}

\author{
Rasha A. Al-Timari ${ }^{1}$
}

\section{ABSTRACT}

Background: Caesarean section is increasing as a means of delivery. A decision on this choice need to be joint among doctors, women and others. An appropriate decision will be facilitated with good knowledge of women about this operation.

Objectives: To assess the knowledge and attitude of women in the reproductive age about Caesarean Section.

Methods: This is a descriptive cross sectional study carried out in Basrah city among women in the reproductive age group who visited two primary health centers(Al-Razi and Al-Seef centers). The study involved 242 women with age range from 15-45 years,

Results: History of one or more Caesarean Section was reported by $35.5 \%$. The results of study showed that all the women involved in this study heard about Caesarean Section and a good number of them had an idea about the effect of Caesarean Section on the number of children, the possibility of vaginal delivery after first Caesarean Section and about some chronic diseases (hypertension and diabetes) which might increase the prospect of Caesarean Section. Majority of participants preferred normal vaginal delivery because of rapid recovery and less complication than Caesarean Section.

Conclusions: Caesarean section is a prevailing practice in Basrah city. Women had good knowledge about it but in general they prefer normal vaginal delivery.

Key words: Basrah, Caesarean section, Knowledge, attitude

$$
\begin{aligned}
& \text { نمط معرفة وموقف النساء في سن الإنجاب عن العملية القيصرية في مدينة البصرة } \\
& \text { الخحلفية: تتزايد نسب الولادة بالعملية القيصرية واللجوء اليها يتطلب قرارا مشتركا بين الطبيب وإلام وربما آخرين ومعرفة } \\
& \text { المرأة الجيدة يسهل اتخاذ القرار المناسب. } \\
& \text { الطرائق: أجريت هذه الدراسة الوصفية المقطعية في مدينة البصرة على النساء اللواتي في سن الإنجاب في اثنين من المراكز } \\
& \text { الصحية الأولية(مركز الرازي ومركز السيف) وذلك لتقييم مدى معرفتهم وموقفهم من الولادات القيصرية. هذه الدراسة }
\end{aligned}
$$

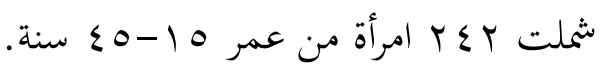

$$
\begin{aligned}
& \text { الهلف: تقييم معارف ومواقف النساء في سن الإنجاب حول العملية القيصرية. } \\
& \text { النتائج: كان ه،هץ\% من النساء قد خضعن لعملية قيصرية واحدة أو أكثر. أظهرت نتائج الدراسة ان جميع النساء } \\
& \text { المشمولات في الدراسة قد سمعوا مسبقا بالولادات القيصرية وان عدد كبير منهم لديه معرفة بتأثير العمليات في تحديد } \\
& \text { عدد الأطفال وبإمكانية الولادة الطبيعية بعد العملية القيصرية الأولى وكان لديهم معرفة ببعض الأمراض المزمنة التي قد } \\
& \text { تزيد من احتمال إجراء العملية القيصرية. معظم النساء في هذه الدراسة يفضلن الولادة الطبيعية بسبب سرعة الشفاء وقلة } \\
& \text { المضاعفات مقارنة بالولادة القيصرية. ويمكن الاستنتاج بان إجراء العمليات القيصرية في مدينة البصرة شائع وعموما } \\
& \text { يمتلك النساء معرفة جيدة عنها لكن معظمهم يفضلون الولادة الطبيعية. } \\
& \text { الكلمات المفتاحية: بصرة، العملية القيصرية، المعرفة، المستوى }
\end{aligned}
$$

${ }^{1}$ MBChB, FIBMS, Department of Community Medicine, College of Medicine, University of Basrah, Basrah, Iraq 


\section{INTRODUCTION}

aesarean Section (CS) is one of the common surgical operations for women worldwide. ${ }^{[1]}$ It means delivery of the fetus through an abdominal and uterine incision. ${ }^{[2]}$ The rate of CS is increasing all over the world to a level beyond the recommended level of $10 \%$, yet, this increase do not further decrease the risk of maternal and perinatal death. ${ }^{[3,4]}$ There is a considerable variation in the rate of CS between high and low income countries and between different areas within the same countries. ${ }^{[5,6]}$ One research suggested that increasing rate of $\mathrm{CS}$ is attributed to structural factors, to the service supply and to the compensation structure rather than to woman's ability to pay or her desire to have CS. ${ }^{[7]}$ There are many factors contributed for the increasing rate of CS. Some of these factors are related to medical causes to save the life of mother or the fetus, change in the obstetric practices and technologies or non-medical factors such as request by mother, fear of the pain associated with normal vaginal delivery. ${ }^{[7]}$ In Iraq, there is a rapid expansion of private health sectors in recent years. ${ }^{[8]}$ The poor governmental oversight of this sector lead to elevate the concerns about possible increase in the physician induced demand for health care including cesarean sections ${ }^{[9-11]}$ The knowledge of women about CS affect their ability to give informed consent to this operation. Evidence shows that patients who are more knowledgeable about their condition are more able to participate in shared decision making. ${ }^{[12]}$ The perception of women about CS are driven from the information that they receive from different sources modulated by culture and beliefs that can significantly affect the knowledge and attitude of women towards CS. ${ }^{[13]}$

The aim of this study is to investigate the knowledge and attitude about CS among mothers in childbearing age attending primary health centers in Basrah city.

\section{SUBJECTS AND METHODS}

This is a cross sectional study which was carried out in Basrah city during 2017 in two primary health care centers (Al-Razi and Al-Seef centers) and included mothers in reproductive age group (15-45 years old) who had at least one child and they attended health care centers for antenatal or postnatal care. A sample of 242 mothers has been included in the study. The data were collected by using a questionnaire form which was filled by direct interview with each mother. The purpose of the study was explained to each mother before the interview and no one refused to participate. The questionnaire included variables related to sociodemographic characteristics (age, marital status, education, occupation, address), and to the knowledge and attitude of mothers regarding caesarian section.

The data collected were entered into computer using SPSS programme version 20 and handled by using descriptive statistics (frequencies and percentage).

\section{RESULTS}

\section{Sociodemographic characteristics:}

(Table-1), shows the distribution of the studied women according to their sociodemographic characteristics. Regarding age, the highest percentage was for the age group between 25 and 29 years $(27.7 \%)$ followed by the age group 30-34 years $(23.1 \%)$. All women except three were engaged in active marital life. The other three were either widow or divorced. Educationwise, intermediate and primary levels were the most frequent categories $(36 \%$ and $24.8 \%$ in that order). With respect to work, $87.2 \%$ were house wives and only $12.8 \%$ were engaged in paid jobs. 
Table 1. Sociodemographic characteristics of studied women.

\begin{tabular}{|c|c|c|}
\hline Age & No. & $\%$ \\
\hline $15-$ & 13 & 5.4 \\
\hline $20-$ & 44 & 18.2 \\
\hline $25-$ & 67 & 27.7 \\
\hline $30-$ & 56 & 23.1 \\
\hline $35-$ & 35 & 14.5 \\
\hline $40-45$ & 27 & 11.2 \\
\hline Marital status & No. & $\%$ \\
\hline married & 239 & 98.8 \\
\hline widow & 1 & 0.4 \\
\hline divorced & 2 & 0.8 \\
\hline Education & No. & $\%$ \\
\hline illiterate & 7 & 2.9 \\
\hline $\begin{array}{l}\text { Just read and } \\
\text { write }\end{array}$ & 14 & 5.8 \\
\hline primary & 60 & 24.8 \\
\hline intermediate & 87 & 36.0 \\
\hline secondary & 39 & 16.1 \\
\hline collage & 35 & 14.4 \\
\hline Occupation & No. & $\%$ \\
\hline Worker & 31 & 12.8 \\
\hline Housewife & 211 & 87.2 \\
\hline Total & 242 & 100.0 \\
\hline
\end{tabular}

Experience with CS: (Table-2), shows the distribution of women according to their past history of caesarean section. Just under two thirds of the studied women $(64.5 \%)$ gave history of vaginal delivery, $25.6 \%$ delivered by caesarean section and $9.9 \%$ had the history of both vaginal delivery and caesarean section.
Table 2. Frequency distribution table shows distribution of study women according to the history of CS

\begin{tabular}{|c|c|c||}
\hline History of cs & Frequency & Percentage \\
\hline Only CS & 62 & 25.6 \\
\hline No CS & 156 & 64.5 \\
\hline $\begin{array}{c}\text { Both vaginal } \\
\text { delivery and CS }\end{array}$ & 24 & 9.9 \\
\hline Total & 242 & 100.0 \\
\hline
\end{tabular}

Knowledge of CS: (Table-3), shows the distribution of women according to their knowledge about caesarean section. All the women who participated in this study were familiar with CS, the source of information for most of them were the public (relatives and neighbors who were exposed to such operation). More than three quarters $188(77.7 \%)$ said that the CS were limiting the number of children in women who delivered by CS only while the others either said that there was no difference between vaginal delivery and CS or they did not know. The percentage of women who believed that the mothers who were underwent CS for the first time had a chance to delivered vaginally in the next pregnancy was $66.6 \%$ while the others disagree with them and five women had no idea about this aspect. There was no great difference between the women who thought that the doctor was the only person who made a decision about CS and women who knew that women should be involved in making a decision for CS. In addition $58.9 \%$ of the women had an idea about some chronic disease which might increase the risk for CS while the others either did not know or they said that there were no chronic disease that affect CS. Majority of studied women (71.9\%) thought that the rate of CS will be increasing with time. 
Table 3. Distribution of the studied women according to their knowledge about CS.

\begin{tabular}{|c|c|c|}
\hline Have you heard about CS & Frequency & $\%$ \\
\hline Yes & 242 & 100.0 \\
\hline No & 0 & 0.00 \\
\hline $\begin{array}{c}\text { What is (are) the source(s) of } \\
\text { your information }\end{array}$ & Frequency & $\%$ \\
\hline Public including relatives & 188 & 77.7 \\
\hline Doctors & 26 & 10.7 \\
\hline Social media & 5 & 2.1 \\
\hline More than one source & 23 & 9.5 \\
\hline $\begin{array}{l}\text { Do you know that CS limits the } \\
\text { number of children a woman } \\
\text { would have in the future? }\end{array}$ & Frequency & $\%$ \\
\hline Yes & 188 & 77.7 \\
\hline No & 25 & 10.3 \\
\hline Do not know & 29 & 12.0 \\
\hline $\begin{array}{c}\text { The first CS means all the next } \\
\text { deliveries are by CS }\end{array}$ & Frequency & $\%$ \\
\hline Yes & 162 & 66.9 \\
\hline No & 75 & 31.0 \\
\hline Do not know & 5 & 2.1 \\
\hline $\begin{array}{c}\text { The doctor is the only person } \\
\text { who decides on the CS }\end{array}$ & frequency & $\%$ \\
\hline Yes & 115 & 47.5 \\
\hline No & 127 & 52.5 \\
\hline $\begin{array}{c}\text { Are there any chronic diseases } \\
\text { which may increase the } \\
\text { prospect of CS }\end{array}$ & frequency & $\%$ \\
\hline Yes & 142 & 58.7 \\
\hline No & 16 & 6.6 \\
\hline Do not know & 84 & 34.7 \\
\hline $\begin{array}{l}\text { Do you think that the rate of } \\
\text { CS will be increasing in Basrah? }\end{array}$ & frequency & $\%$ \\
\hline yes & 174 & 71.9 \\
\hline No & 15 & 6.2 \\
\hline Do not know & 53 & 21.9 \\
\hline Total & 242 & 100.0 \\
\hline
\end{tabular}

Attitude towards CS: (Table-4), shows the distribution of women according to their attitude towards CS. The highest percentage of women in this study preferred the vaginal delivery (93.8\%) over CS $(6.2 \%)$.

Table 4. Distribution of the studied women according to their attitude towards CS.

\begin{tabular}{||c|c|c||}
\hline $\begin{array}{c}\text { Which way of delivery } \\
\text { you prefer? }\end{array}$ & Frequency & $\%$ \\
\hline Normal vaginal delivery & 227 & 93.8 \\
\hline CS & 15 & 6.2 \\
\hline Total & 242 & 100.0 \\
\hline
\end{tabular}

\section{DISCUSSION}

This study involved women in reproductive age group whose age ranged between 15-45 years, $98.8 \%$ of them were married. Most of them had an intermediate or primary education and they were house wives. The proportion of women who had at least on caesarean section (range 1-4 CSs) were $86(35.5 \%)$. All the women who participated in this study heard about CS and this result agrees with other study which was carried out in Ghana among antenatal clinic attendants in Cape Coast, ${ }^{[14]}$ and a study which was carried out in urban Nigeria. ${ }^{[13]}$ Regarding the source of information about CS, most of the studied women heard about CS from their relatives and neighbors who had a history of such operation and this is important because the knowledge and perception of participants about CS would be much affected by what did they hear from people which were vary from one to other according to their conditions. A study carried out among Trinidadian women also showed that the main source of information about CS was friends or relative in about $50 \% .{ }^{[15]}$ High percentage of women in this study knew that the CS is limiting the number of children to three or four. Also they knew that the mothers after first CS had a chance for 
vaginal delivery which agreed with another study in Northwest Nigeria. ${ }^{[16]}$ The percentage of women who expressed that the doctor is the only person who is responsible for making a decision about CS is nearly equal to percentage of those who thought that the mother should be involved in the decision making process at least regarding elective cases. Good number of participants had an idea about some chronic diseases that might increase the rate of CS which included hypertension and diabetes. High percentage of women thought that the rate of CS increased with time and when asked them about the reason, most of them said that early marriage and afraid from pain associated with normal vaginal delivery were responsible for increase in CS rate. The majority of women in our study preferred vaginal delivery $(93.7 \%)$ because of rapid recovery, less complication and no need for anesthesia, but they accepted CS when the doctor decide it to save the life of the mother or the fetus. Fewer numbers of women preferred CS because they feared from pain associated with vaginal delivery and they thought that it was more save to the fetus and this agreed with other studies in Ghana ${ }^{[14]}$ and Northwest Pakistan. ${ }^{[17]}$ In conclusion, we can conclude that the knowledge of women about caesarean section is good but we need to promote the health education in primary health centers to ensure that the all information that received are right and to eliminate the negative cultural perception of people towards caesarean section.

\section{REFERENCES}

1. Bamigboye AA, Hofmeyr GJ. Non-closure of peritoneal surface at caesarean section-a systemic review. SAfr Med J 2005; 95: 123-126.

2. Belizean AF. Caesarean section lancet 2006; 368: 1472-1475.

3. Stanon C, Holtz S. Level and trends in caesarean birth in the developing world. Stud Fam Plann. 2006; 37(1): 41-48

4. Ye J, Zhang J, Mikolajczyk R, Torloni MR, Gülmezoglu AM, Betran AP. Association between rates of caesarean section and maternal and neonatal mortality in the 21 century: a worldwide population-based ecological study with longitudinal data. BJOG. 2016; 123(5): 745-753.

5. Althabe F, Sosa C, Belizán J, Gibbons L, Jacquerioz F, Bergel E. Caesarean section rates and maternal and neonatal mortality in lowmedium and high-income countries: an ecological study. Birth. 2006; 33(4): 270-7.

6. Villar J, Valladares E, Wojdyla D, Zavaleta N, Carroli G, Velazco A, et al. Caesarean delivery rates and pregnancy outcomes: the 2005 WHO global survey on maternal and perinatal health in Latin America. Lancet. 2006; 367(9525): 1819-1829.

7. Feng XL, Xu L, Guo Y, Ronsmans C. Factors influencing rising caesarean section rates in China between 1988 and 2008. Bull World Health Organ. 2012; 90(1): 30-39A.

8. Anthony CR, Moore $M$, Hilborne LH, Mulcahy AW. Health sector reform in the Kurdistan Region-Iraq: financing reform, primary care, and patient safety. Santa Monica: RAND Corporation; 2014.

9. Shabila NP. Provider-induced demand in healthcare market: the case of Iraqi Kurdistan region. Zanco J Med Sci. 2013; 17(3): 482-483.

10. Maternal Health Task Force. Maternal health and C-sections in Iraq. Massachusetts: Harvard School of Public Health; 2011.

11. Rise in Iraqi C-sections worries doctors. NY: Fox News Network; 2011. http://www.foxnews.com/world/2011/08/16/ris e-in-iraqi-csections- Accessed on December 20, 2017.

12. Coulter A, Parsons S, Askham J. Where Are the Patients in Decision-Making About Their Own Care? Copenhagen, Denmark: WHO, Regional Office for Europe; 2008.

13. Aziken M, Omo-Aghoja L, Okonofua F. Perceptions and attitudes of pregnant women towards caesarean section in urban Nigeria. Acta Obstet Gynecol Scand. 2007; 86(1): 42-47.

14. KojoPrah J, Kudom A, UwumbornyiLasim O, Kwasi Abu E. Knowledge, Attitude and Perceptions of pregnant women towards Caesarean Section among antenatal clinic attendants in Cape Coast, Ghana Texila International Journal of Public Health. Mar 2017; 5(1).

15. K Mungrue, C Nixon, Y David, D Dookwanh, S Durga, $K$ Green, and $H$ Mohammed. $T$. 
Trinidadian women's knowledge, perception and preferences regarding Caesarean Section: How they make choises. Int J Women Health.2010; 2: 387-391.

16. Ashimi AO, Amole TG, Aliyu LD. Knowledge and attitude of pregnant women to Caesarean Section in Semi-Urban community in Northwest Nigeria. J West AfrColl Surg. 2013; (2): 46-61.
17. Qazi Q, Akhter Z, Khan K, Khan AH. Pregnant women view regarding Caesarean Section in Northwest Pakistan. Trop Med Surg 2013; 1: 1. 